\title{
KORELASI PASAR MODAL NEGARA ASEAN-5 DIERA MASYARAKAT EKONOMI ASEAN TERHADAP PELUANG DIVERSIFIKASI INVESTASI INTERNASIONAL
}

\author{
FEBRIYANTO
}

Fakultas Ekonomi Universitas Muhammadiyah Metro

Email: febriyanto0223027901@gmail.com

\section{FIDUSIA}

Jurnal Ilmiah Keuangan dan Perbankan

ISSN Cetak : 2621-2439

ISSN Online : 2621-2447

Katakunci: Investasi, Diversifikasi, Portofolio.

\section{ABSTRAK}

Penelitian ini bersifat deskriptif korelasional, yang menggunakan data sekunder Indeks Harga Saham Gabungan bulanan Bursa Efek Pasar Modal ASEAN 5 Tahun 2016. Sesuai dengan teori Markowitz (1952), manfaat utama diversifikasi secara kuantitatif dengan menggunakan portofolio yang terdiri atas dua aset berisiko. Melalui matematika sederhana, Markowitz mampu membuktikan jika risiko portofolio dapat menjadi minimum jika kedua aset itu mempunyai koefisien korelasi negatif.

Berdasarkan analisis data tentang nilai korelasi, pasar modal periode Juni Desember 2016 dari 5 negara yang memiliki nilai korelasi negatif yaitu: (IndonesiaSingapura), (Malaysia-Singapura), dan (Philipina-Singapura). Periode semester ke2 di tahun 2016, menunjukkan peluang investasi untuk memaksimalkan keuntungan dan meminimalkan risiko diversifikasi investasi pada negara (Indonesia-Singapura), (Malaysia-Singapura), (Philipina-Singapura). Artinya jika investor yang rasional menginginkan return yang tinggi dan risiko yang rendah, maka negara (IndonesiaSingapura), (Malaysia-Singapura), dan (Philipina-Singapura) yang menjadi alternatif pilihan Investasi. Peluang ini tentu perlu dimanfaat dengan baik oleh para investor untuk memaksimalkan investasinya, namun tetap memperhatikan berbagai variabel yang dapat mempengaruhi hasil investasi pada sarana investasi pasar modal.

Katakunci: Investasi, Diversifikasi, Portofolio. 


\section{Latar Belakang}

Pasar modal merupakan pasar ekuitas dengan masa pengembalian pinjaman lebih dari satu tahun, berbeda dengan pasar surat berharga yang lain dengan masa pengembalian jangka pendek, yaitu kurang dari satu tahun seperti pasar uang (Jogiyanto, 2008). Berdasarkan konsep tersebut, pasar modal memiliki peranan penting terkait pengembangan perekonomian. Pasar modal dapat mendeskripsikan kondisi kesehatan dan pertumbuhan ekonomi suatu negara, ketika kebijakankebijakan pemerintah dan kondisi ekonomi suatu negara baik pada sudut pandang investor, maka akan diimbangi dengan harga-harga saham yang akan naik atau meningkat dan kondisi ini mampu meningkatkan nilai indeks harga saham gabungan dari suatu negara, begitu juga sebaliknya. Berdasar peristiwa tersebut, berbagai macam usaha dilakukan setiap negara untuk meminimalisasi risiko yang ada dan mengoptimalkan sumber daya yang dimiliki. Usaha yang dilakukan salah satunya yaitu melakukan integrasi ekonomi terutama pasar modal yang memberikan gambaran kegiatan pasar yang sebenarnya terjadi. Integrasi pasar dapat terwujud jika dua pasar yang terpisah memiliki pergerakan indeks yang sama dan memiliki korelasi diantara pergerakan indeksnya (Click dan Plummer, 2003). Pergerakan harga saham ini disebabkan oleh beberapa faktor yang memberi pengaruh, sebagai contoh adalah volume perdagangan saham, persepsi dari investor dan berbagai berita fundamental yang lain. Chen dan Siems (2004) mengatakan bahwa harga dari saham individual merefleksikan dari harapan para investor dan ketakutan terhadap kondisi yang akan datang, pergerakan harga saham dapat berupa gelombang naik turun yang selalu aktif.

Karolyi dan Stulz (1996) menemukan bahwa korelasi dan kovariansi dari pasar saham menjadi tinggi pada saat pasar mengalami banyak pergerakan. Adanya korelasi pasar modal menggambarkan pasar yang terbuka dan terpadu. Implikasi dari korelasi pasar modal tersebut menyebabkan kecenderungan harga dan imbal hasil aset keuangan yang diperdagangkan di berbagai negara akan sama dalam basis mata uang yang sama.

Berbagai negara telah banyak membentuk jalinan kerjasama sebagai bentuk gambaran pasar yang terbuka dan terpadu. ASEAN misalnya, sejak tahun 1967 negara-negara Asia Tenggara (ASEAN) melakukan perhimpunan kerjasama. Perhimpunan negara-negara tersebut ada awalnya merupakan kerjasama bidang politik, namun kerjasama tersebut berkembang menjadi kerjasama dalam bidang ekonomi.

Perkembangan kerjasama dalam bidang ekonomi bermula dari konsep Preferential Trade Arrangement (PTA) setelah itu berubah menjadi Free Trade Area (FTA). Perubahan terakhir kerjasama ASEAN menjadi pembentukan ASEAN Economic Community (AEC). Konsep ini dipertegas dalam KTT ASEAN Oktober 2003 di Bali dalam Deklarasi ASEAN Concord II (Bali Concord II). 
ASEAN Economic Community (AEC) atau Masyarakat Ekonomi ASEAN (MEA) adalah perwujudan dari hasil pemikiran negara anggota ASEAN sebagai kawasan yang makmur dan memiliki daya saing tinggi. Pembentukan MEA pada tahun 2015 berfungsi sebagai wilayah basis produksi dan pasar tunggal. Program MEA meliputi kebebasan aliran barang, tenaga kerja, aliran modal, juga bertujuan dalam rangka mengurangi kemiskinan dan kesenjangan sosial ekonomi.

Roadmap Integrasi ASEAN (RIA) bidang finansial (RIA-Fin) yang mencakup 4 bidang, yaitu, pengembangan pasar modal, liberalisasi neraca modal, liberalisasi jasa keuangan, dan kerja sama nilai tukar diwujudkan dalam rangka membentuk kerjasama pasar modal yang saling terkait karena terintegrasi, meningkatkan perdagangan intra kawasan dan memperdalam integrasi ekonomi regional.

Pasar modal ASEAN yang terintegrasi, akan meningkatkan perannya dalam peningkatan pembangunan ekonomi negara-negara ASEAN. Liaw (2005) mengatakan, peran pasar modal ini penting, karena pasar modal merupakan sumber pendanaan jangka panjang bagi korporasi dan untuk memperoleh tambahan nilai keuntungan bagi investor. Bursa-bursa saham yang terintegrasi akan memberikan peluang bagi perusahaan-perusahaan untuk mendapatkan modal secara efisien. Sedangkan bagi para investor dapat menanamkan modalnya pada sekuritas atau investasi portofolio.

Berdasarkan penelitian Karolyi dan Stulz (1996) terintegrasinya pasar modal akan meningkatkan peran pasar modal dalam pembangunan ekonomi negara. Terintegrasinya bursa-bursa saham akan memberikan peluang bagi perusahaan-perusahaan untuk memperoleh modal secara efisien. Sementara bagi investor dapat menanamkan modalnya pada sekuritas atau investasi portofolio. Sejauh mana pasar keuangan internasional terintegrasi, akan menjadi isu yang menarik bagi pembuat kebijakan dan pelaku pasar.

Beberapa peneliti yang telah melakukan kajian terhadap integrasi pasar modal di ASEAN yang memberikan beberapa kesimpulan. Dimulai dengan temuan oleh Click dan Plummer (2005) dengan menggunakan teknik time series kointegrasi untuk menguji adanya korelasi pada pasar ASEAN. Dari penelitian tersebut dapat di simpulkan bahwa kelima negara ASEAN telah terintegrasi dalam perekonomian namun tida sepenuhnya tersegmentasi oleh perbatasan nasional. Berikut adalah perkembangan IHSG dilima negara anggota ASEAN tahun 2016. 
Tabel 1. Data Indeks Harga Saham Gabungan Pasar Modal Negara ASEAN-5

\begin{tabular}{|c|c|c|c|c|c|}
\hline Tanggal & Indonesia & Malaysia & Singapura & Pilipina & Thailand \\
\hline $25 / 12 / 2016$ & 5296,71 & 1641,73 & 2880,76 & 6840,64 & 1542,94 \\
\hline 18/12/2016 & 5027,7 & 1617,15 & 2871,05 & 6563,67 & 1509,98 \\
\hline 11/12/2016 & 5231,65 & 1637,79 & 2937,86 & 6850,71 & 1522,51 \\
\hline $04 / 12 / 2016$ & 5308,13 & 1641,42 & 2956,13 & 7043,16 & 1526,32 \\
\hline 27/11/2016 & 5245,96 & 1628,96 & 2919,37 & 6886,74 & 1501,66 \\
\hline 20/11/2016 & 5122,1 & 1627,26 & 2859,33 & 6889,78 & 1500,4 \\
\hline 13/11/2016 & 5170,11 & 1623,8 & 2838,65 & 7067,73 & 1473,86 \\
\hline 06/11/2016 & 5231,97 & 1634,19 & 4,6 & 6975,09 & 1494,53 \\
\hline $30 / 10 / 2016$ & 5362,66 & 1648,24 & 2788,8 & 7227,37 & 1485,7 \\
\hline 23/10/2016 & 5410,27 & 1670,27 & 2816,26 & 7404,8 & 1494,44 \\
\hline $16 / 10 / 2016$ & 5409,24 & 1669,98 & 2831,06 & 7650,22 & 1500,37 \\
\hline 09/10/2016 & 5399,88 & 1658,97 & 2815,24 & 7389,3 & 1477,61 \\
\hline 02/10/2016 & 5377,15 & 1665,38 & 2875,24 & 7578,29 & 1504,34 \\
\hline 25/09/2016 & 5364,8 & 165 & 47 & 762 & 1483,21 \\
\hline 18/09/2016 & 5388,91 & 1670,99 & 2856,95 & 7723,6 & 1492,88 \\
\hline $11 / 09 / 2016$ & 5267,77 & 165 & 45 & 755 & 1479,07 \\
\hline 04/09/2016 & 5281,92 & 1686,44 & 2873,33 & 7581,79 & 1445,28 \\
\hline 28/08/2016 & 5353 & 1671,79 & 92 & 7807,42 & 1521,48 \\
\hline $21 / 08 /$ & 5438 & 16 & & 78 &, 41 \\
\hline $14 / 08 / 2016$ & 5416,04 & 1687,68 & 2844,02 & 7930,75 & 1538,76 \\
\hline 07/08/2016 & 5377,2 & 1684,15 & 2867,4 & 795 & 1552,64 \\
\hline 31/07/2016 & 5420,25 & 1664,04 & 2828,17 & 7970,35 & 1518,69 \\
\hline 24/07/2016 & 5215,99 & 1653,26 & 2868,69 & 7963,11 & 1524,07 \\
\hline 17/07/2016 & 5197,25 & 1657,42 & 29 & 8025,35 & 1509,13 \\
\hline 10/07/2016 & 5110,18 & 1668,4 & 35 & 8030,06 & 1492 \\
\hline 26/06/2016 & 4971,58 & 1646,22 & 37 & 7830,35 & 1444,99 \\
\hline 19/06/2016 & 4834,57 & 1634,05 & ,39 & 7629,72 & 1413,19 \\
\hline $12 / 06 / 2016$ & 4835,14 & 1624,18 & 2763,42 & 7622,07 & 1421,32 \\
\hline 05/06/2016 & 4848,06 & 1641,22 & 2822,97 & 7509,94 & 1429,21 \\
\hline 29/05/2016 & 4853,92 & 1636,46 & 2809,23 & 7514,22 & 1436,43 \\
\hline $22 / 05 / 2016$ & 4814,73 & 1637,19 & 2802,51 & 7411,68 & 1412,67 \\
\hline $15 / 05 / 2016$ & 4711,88 & 1628,79 & 2763,82 & 7299,03 & 1385,86 \\
\hline 08/05/2016 & 4761,71 & 1628,26 & 2734,91 & 7436,79 & 1394,69 \\
\hline $01 / 05 / 2016$ & 4822,6 & 1649,36 & 2730,8 & 6991,87 & 1390,7 \\
\hline 24/04/2016 & 4838,58 & 1672,72 & 2838,52 & 7159,29 & 1404,61 \\
\hline $17 / 04 / 2016$ & 4914,74 & 1717,96 & 2940,43 & 7255,39 & 1410,81 \\
\hline $10 / 04 / 2016$ & 4823,57 & 1727,99 & 2923,94 & 7321,3 & 1385,42 \\
\hline $03 / 04 / 2016$ & 4846,7 & 1718,4 & 2808,32 & 7247,2 & 1369,64 \\
\hline 27/03/2016 & 4843,19 & 1710,55 & 2818,49 & 7245,13 & 1400,72 \\
\hline 20/03/2016 & 4827,09 & 1703,79 & 2847,39 & 7360,05 & 1394,78 \\
\hline $13 / 03 / 2016$ & 4885,71 & 1716,34 & 2906,8 & 7306,74 & 1382,96 \\
\hline 06/03/2016 & 4813,78 & 1696,54 & 2828,86 & 7098,64 & 1393,41 \\
\hline 28/02/2016 & 4850,88 & 1692,49 & 2837 & 6899,07 & 1379,53 \\
\hline 21/02/2016 & 4733,15 & 1663,44 & 2649,38 & 6771,3 & 1343,07 \\
\hline $14 / 02 / 2016$ & 4697,56 & 1674,88 & 2656,87 & 6792,06 & 1320,19 \\
\hline
\end{tabular}




\begin{tabular}{rrrrrr}
\hline Tanggal & Indonesia & Malaysia & Singapura & Pilipina & Thailand \\
\hline $\mathbf{0 7 / 0 2 / 2 0 1 6}$ & 4714,39 & 1643,74 & 2539,95 & 6654,45 & 1276,49 \\
$\mathbf{3 1 / 0 1 / 2 0 1 6}$ & 4798,95 & 1662,46 & 2623,21 & 6765,13 & 1306,29 \\
$\mathbf{2 4 / 0 1 / 2 0 1 6}$ & 4615,16 & 1667,8 & 2629,11 & 6687,62 & 1300,98 \\
$\mathbf{1 7 / 0 1 / 2 0 1 6}$ & 4456,74 & 1625,21 & 2577,09 & 6208,05 & 1268,03 \\
$\mathbf{1 0 / 0 1 / 2 0 1 6}$ & 4523,98 & 1628,55 & 2630,76 & 6449,5 & 1245,85 \\
$\mathbf{0 3 / 0 1 / 2 0 1 6}$ & 4546,29 & 1657,61 & 2751,23 & 6575,43 & 1244,18 \\
\hline
\end{tabular}

Sumber: investing.com

Sampai saat ini, antar negara ASEAN masih terdapat perbedaan-perbedaan regulator (peraturan). Maka keinginan memiliki pasar modal tunggal di kawasan ASEAN perlu kebijakan yang mengatur perpajakan, perlindungan investor dan penyelesaian sengketa. Setiap negara harus memprioritaskan dan mensikronkan program negaranya masing-masing, integrasi harus dilakukan para pemangku kepentingan, setiap negara harus berusaha meningkatkan likuditas di pasar ASEAN.

Masalah integrasi pasar saham negara-negara ASEAN merupakan sangat penting. Tingkat kepentinganya menjadi tema kajian yang menarik untuk diteliti, mengingat penerapan pasar tunggal dalam perekonomian kian tinggal menghitung hari, sehingga akan lebih menarik dan perlu untuk mengetahui serta membuktikan apakah pasar modal di kawasan lima negara anggota ASEAN (Indonesia, Malaysia, Singapura, Philipina dan Thailand) tahun 2016?

\section{Landasan Teori}

\subsection{Diversifikasi Internasional}

Konsep diversifikasi berawal dari Markowitz pada tahun 1952. Secara kuantitatif melalui matematika sederhana menggunakan portofolio yang terdiri atas dua aset berisiko, Markowitz mampu membuktikan jika risiko portofolio dapat menjadi minimum jika kedua aset itu mempunyai koefisien korelasi negatif. Diversifikasi merupakan strategi investasi melalui penempatan dana ke dalam berbagai instrument investasi dengan tingkat risiko dan potensi keuntungan yang berbeda.

Rodoni (2008) mengatakan, faktor yang penting dalam diversifikasi ialah korelasi yang rendah antara keuntungan, semakin rendah korelasi ini, maka semakin besar manfaat diversifikasi portofolio. Pendapat Lessard (1973) menujukan bahwa, koefisien determinasi berhubungan secara terbalik dengan keinginan menginvestasikan disatu negara. Kontribusi return melalui diversifikasi internasional dalam jangka panjang yang diperoleh investor akan lebih tinggi dibanding investasi yang hanya dilakukan pada pasar modal lokal. Besarnya manfaat yang akan diperoleh investor akan sangat tergantung dari koefisien korelasi, resiko dan tingkat return di masing-masing pasar modal tersebut (Tandelilin, 2010). 


\subsection{Korelasi Pasar Modal}

Konsep tentang korelasi pasar modal merupakan kegiatan yang dilakukan di satu kawasan ekonomi tanpa frontier (batas antar negara), dimana setiap investor dari setiap negara anggota bisa bergerak bebas sebagaimana dalam negara sendiri. Tujuan dari kegiatan ini yaitu mencapai tingkat kegunaan yang paling optimal dan pada akhirnya mampu mendorong terwujudnya tingkat kesejahteraan yang sama.

Modal atau kapital akan bisa berpindah secara leluasa diantara negara-negara ASEAN, yang secara teoritis memungkinkan terjadinya penanaman modal secara efisien. Dengan demikian, melalui konsep ini menurut Widyahartono, (2010), setiap pemilik modal baik WNI maupun waga negara lainnya akan bebas dan leluasa memindahkan investasinya dari Indonesia ke negara lain begitu juga sebaliknya sehingga akan mencapai efisiensi tertinggi tanpa bisa dicegah.

Menurut Husnan, (2004) pasar modal internasional yang terintegrasikan sepenuhnya (artinya tidak ada hambatan apapun untuk memiliki sekuritas di setiap pasar modal, dan juga tidak ada hambatan dalam capital inflow atau outflow) akan menciptakan biaya modal yang Iebih rendah daripada seandainya pasar modal tidak terintegrasikan. ini terjadi karena para pemodal bisa melakukan diversifikasi investasi dengan lebih luas sampai antar negara. Karena risiko yang relevan bagi para pemodal hanyalah risiko yang tidak bisa dihilangkan dengan diversifikasi, maka semakin menarik diversifikasi internasional bagi para pemodal. Semakin kecilnya risiko yang ditanggung pemodal, maka biaya modal akan menjadi lebih kecil.

Menurunnya biaya modal tentu akan membuat investasi makin menguntungkan, jika hal-hal lain sama. Ini akan berarti bahwa investasi akan makin banyak dilakukan, penyerapan tenaga kerja makin besar, dan seterusnya. Jika demikian, pasar modal internasional yang terintegrasikan akan memberikan manfaat yang besar dibandingkan dengan seandainya tersegmentasikan.

Menurt Brook dan Negro (2002), makin terintegrasinya pasar-pasar modal dunia yang ditandai oleh makin tingginya korelasi antara return saham antar bursa saham. Penyebab makin tingginya korelasi yaitu 1. Bias yang makin menurun dalam pilihan portofolio, 2. Beranekaragamnya penjualan dan pendanaan perusahaan-perusahaan, 3. Keadaan sementara, atau konvergensi industri dan koordinasi kebijakan antar negara yang makin tinggi intensitasnya.

Korelasi antar bursa bervariasi dari waktu ke waktu atau correlations are time-varying, menurut Onay (2007). Bervariasinya korelasi ini juga disampaikan oleh Bodie. et al (2005), yaitu meski korelasi return antar bursa penting dalam keputusan diversifikasi portofolio, perhitungan korelasi return yang menggunakan nilai mean dan variance, hanya memberikan indikasi jangka pendek dan tidak memberikan petunjuk pada pergerakan pasar finansial dalam jangka panjang. Berkaitan dengan sifat jangka pendek korelasi, sehingga peramalan jangka panjang diperlukan 
ukuran yang lebih tepat dari saling ketergantungan dan arah gerak-umum dari harga saham-saham pada berbagai bursa. Menurut Onay, (2007).

Persoalan saling ketergantungan dan pergerakan umum di atas menunjuk kepada konsep kointegrasi yang menurut Bierens (2006), menyatakan bahwa konsep kointegrasi Granger merupakan tolok ukur dalam melakukan diversifikasi yang didasarkan data harga pasar.

\subsection{Penelitian Terdahulu}

Rencana penelitian ini merupakan replikasi dari hasil penelitian yang telah banyak dilakukan para peneliti sebelumnya, diantaranya:

a. Click dan Plummer (2003).

Melalui analisis time series menggunakan data harian dan mingguan indeks harga saham komposit Juli 1998 - Desember 2002 di lima Negara ASEAN. Penelitian tersebut yang Membahas integrasi pasar modal ASEAN setelah krisis moneter, mengungkapkan bahwa bursa saham lima Negara ASEAN terintegrasi dalam pengertian ekonomi, namun integrasinya belum lengkap.

b. Kiang-Ping et.al. (2003).

Studi mengenai integrasi bursa saham di Jakarta, Kuala Lumpur, Manila, Singapura dan Bangkok dengan menggunakan data bulanan mulai 1998 sampai dengan tahun 2002. Hasil penelitian menyimpulkan ada common force yang menggerakkan bursa saham kelima Negara ASEAN tersebut dalam jangka panjang bergerak bersama, saling bergantung dan sangat terintegrasi dan akan bergerak sebagaimana bagian dari sebuah pasar yang terintegrasi.

c. Mafizatun Nurhayati, (2012).

Meneliti integrasi pasar modal kawasan ASEAN dan menyimpulkan bahwa dalam jangka pendek integrasi pasar modal tidak terjadi tetapi dalam jangka panjang terjadi integrasi pasar modal, walaupun tidak sepenuhnya. Terdapat satu pasar modal yang terintegrasi dengan pasar modal dari negara-negara ASEAN yang lain. Selanjutnya, pasar modal Indonesia terintegrasi dengan pasar modal negara-negara ASEAN yang lain secara signifikan. Perubahan naik turunnya indeks harga saham gabungan di bursa efek Malaysia, Philipina, Singapura dan Thailand berpengaruh positif yang signifikan terhadap indeks harga saham gabungan di bursa efek Indonesia. Masing-masing pasar modal baik bursa efek Malaysia, Philipina, Singapura dan Thailand berpengaruh secara signifikan terhadap pasar modal di bursa efek Indonesia. Di sisi yang lain, pasar modal Indonesia tidak mempunyai pengaruh yang signifikan terhadap pasar modal negara-negara yang lain. Artinya, pasar modal Indonesia ada pada posisi yang rentan, mudah terpengaruh oleh gejolak pasar modal yang terjadi di negara-negara lain khususnya dalam satu kawasan ASEAN. 


\subsection{Kerangka Pikir}

Korelasi pasar modal diartikan sebagai hubungan yang terjadi antar pasar modal dua atau lebih negara-negara dimana jika salah satu pasar mengalami shocks baik berupa perubahan indeks harga saham gabungan, atau yang lain akan memberikan pengaruh baik dalam jangka panjang maupun jangka pendek pasar modal negara yang terintegrasi.

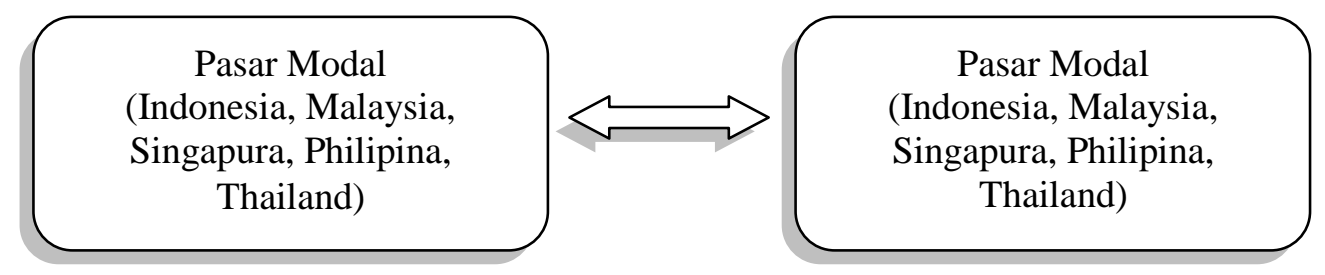

\section{Gambar 1: Kerangka Pikir}

Korelasi yang terjadi bisa positif atau negatif. Jika terjadi korelasi pasar modal, maka hasil analisisnya akan menampilkan trend yang sama untuk tiap negara, dengan kata lain kenaikan atau penurunannya akan terjadi secara bersama-sama dari periode ke periode selanjutnya atau sebelumya. Korelasi indeks harga saham gabungan dalam jangka panjang antar pasar modal antar Negara digunakan untuk mengetahui tingkat dan perkembangan integrasi pasar modal.

\section{Metode Penelitian}

Penelitian ini bersifat deskriptif korelasional, yang menggunakan data sekunder Indeks Harga Saham Gabungan. Data berbentuk time series bulanan Indeks Harga Saham Gabungan Bursa Efek Pasar Modal Tahun 2016. Pengumpulan data melalui situs www.investing.com. Dasar pengambilan data yang digunakan adalah tahun 2016 yaitu satu tahun setelah negara ASEAN bersepakat untuk melakukan kerjasama yang diberlakukan pada awal 2016. Artinya setelah terjadi kesepakatan tersebut, bagaimana arah korelasi pasar modal yang terwujud.

Korelasi pasar modal negara anggota ASEAN akan dianalisis dengan rumus korelasi ganda untuk menghitung dan menganalisis tentang nilai korelasi indeks harga saham gabungan lima negara ASEAN (Indonesia, Malaysia, Singapura, Philipina dan Thailand) dengan uji statistik berikut ini.

$$
R_{y \cdot x_{1} x_{2} x_{3}, x_{4}}=\sqrt{\frac{r_{y \cdot x_{1}}^{2}+r_{y \cdot x_{2}}^{2}+r^{2}{ }_{y \cdot x_{3}}+r^{2}{ }_{y \cdot x_{4}}-2 r_{y \cdot x_{1}} r_{y \cdot x_{2}} r_{y \cdot x_{3}} r_{y \cdot x_{4}} r_{x_{1} \cdot x_{2} x_{3} x_{4}}}{1-r^{2} x_{1} \cdot x_{2} \cdot x_{3} \cdot x_{4}}}
$$

Keterangan:

$$
\begin{array}{ll}
\operatorname{ry~} \mathrm{x}_{1} \mathrm{x}_{2} \mathrm{x}_{3} \mathrm{x}_{4} & =\text { Koefisien krelasi antara indeks saham negara } \mathrm{x}_{1} \mathrm{x}_{2} \mathrm{x}_{3} \mathrm{x}_{4} \text { dan } \mathrm{y} \\
\mathrm{n} & =\text { Jumlah observasi } \\
\mathrm{x}_{1} \mathrm{x}_{2} \mathrm{x}_{3} \mathrm{x}_{4} & =\text { tingkat nilai saham } \mathrm{x}_{1} \mathrm{x}_{2} \mathrm{x}_{3} \mathrm{x}_{4} \\
\mathrm{y} & =\text { tingkat nilai saham } \mathrm{y}
\end{array}
$$




\section{Pembahasan.}

Sesuai dengan teori Markowitz (1952), manfaat utama diversifikasi secara kuantitatif dengan menggunakan portofolio yang terdiri atas dua aset berisiko. Melalui matematika sederhana, Markowitz mampu membuktikan jika risiko portofolio dapat menjadi minimum jika kedua aset itu mempunyai koefisien korelasi negatif. Brigham and Daves, (2004), Risiko dalam suatu investasi itu secara umum dapat dibagi atas dua yaitu: Pertama, Unsistimatik Risk adalah risiko saham atau portofolio yang disebabkan oleh sekuritas atau permasalahan yang dihadapi oleh industri tertentu. Risiko ini dapat dihindari dengan melakukan diversifikasi. Kedua Sistematik Risk (Market Risk) risiko jenis kedua ini adalah resiko yang disebabkan oleh pergerakan pasar secara umum, seperti perubahan ekonomi suatu negara, perubahan pajak dan krisis energi dunia. Risiko ini tidak dapat diminimalkan dengan diversifikasi bahkan investor yang sudah melakukan diversifikasi dengan baikpun akan terkena dampaknya.

Bagian dari analisis bagi investor dalam menanamkan modalnya ke berbagai wilayah investasi, mengetahui arah korelasi pasar investasi merupakan suatu analisis yang penting untuk dilakukan. Sesuai dengan teori Markowitz (1952), investasi akan minimum resiko dan return yang maksimal jika dua aset atau lebih memiliki korelasi negatif. Berikut adalah analisis data yang telah diperoleh:

Tabel 1. Output Korelasi Januari - Juni 2016

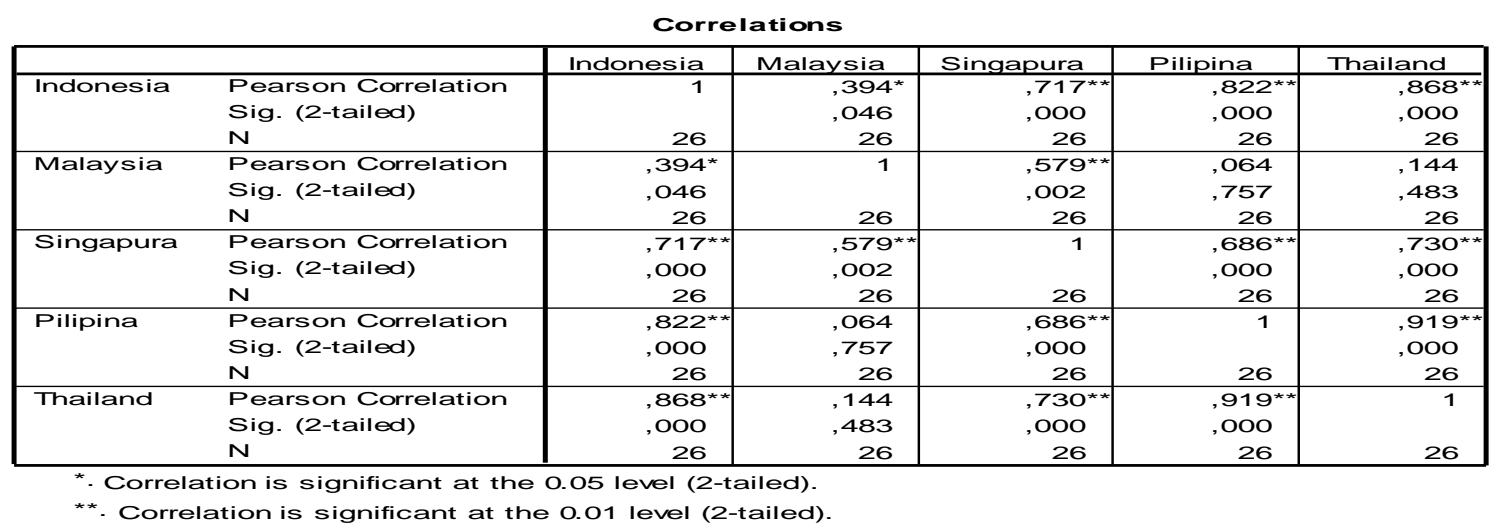

Berdasarkan Tabel 1. Output Korelasi Januari - Juni 2016, Pasar modal periode Januari-Juni 2016 dari 5 negara memiliki korelasi positif dengan korelasi yang signifikan untuk Indonesia dengan Malaysia, Indonesia dengan Singapura, Indonesia dengan Philipina, Indonesia dengan Thailand. Berdasarkan hasil tersebut, untuk semester pertama setelah pemberlakukan MEA 2016, belum menguntungkan jika akan melakukan diversifikasi internasional di pasar modal negara lain. Hal ini melihat dari hasil korelasi ternyata belum ada yang menunjukkan arah korelasi yang negatif, sehingga belum memberikan nilai keuntungan yang maksimum dan risiko yang minimum seperti yang dikatakan Markowitz (1952). 
Tabel 2. Output Korelasi Juli - Desember 2016

\begin{tabular}{|c|c|c|c|c|c|c|}
\hline \multicolumn{7}{|c|}{ Correlations } \\
\hline & & Indonesia & Malaysia & Singapura & Pilipina & Thailand \\
\hline Indonesia & $\begin{array}{l}\text { Pearson Correlation } \\
\text { Sig. (2-tailed) } \\
N\end{array}$ & $\begin{array}{r}1 \\
25\end{array}$ & $\begin{array}{c}, 679^{\star \star} \\
000 \\
25\end{array}$ & $\begin{array}{r}-, 407^{*} \\
, 044 \\
25\end{array}$ & \begin{tabular}{r|}
, $452^{*}$ \\
, 023 \\
25
\end{tabular} & $\begin{array}{r}, 199 \\
, 339 \\
25\end{array}$ \\
\hline Malaysia & $\begin{array}{l}\text { Pearson Correlation } \\
\text { Sig. (2-tailed) } \\
\mathrm{N}\end{array}$ & $\begin{array}{c}, 679^{\star *} \\
, 000 \\
25\end{array}$ & $\begin{array}{r}1 \\
25 \\
\end{array}$ & $\begin{array}{r}-, 184 \\
, 380 \\
25 \\
\end{array}$ & $\begin{array}{c}, 822^{* *} \\
, 000 \\
25\end{array}$ & $\begin{array}{r}, 148 \\
, 480 \\
25 \\
\end{array}$ \\
\hline Singapura & $\begin{array}{l}\text { Pearson Correlation } \\
\text { Sig. (2-tailed) } \\
\mathrm{N}\end{array}$ & $\begin{array}{c}-, 407^{\star} \\
, 044 \\
25 \\
\end{array}$ & $\begin{array}{r}-, 184 \\
, 380 \\
25 \\
\end{array}$ & $\begin{array}{r}1 \\
25 \\
\end{array}$ & $\begin{array}{r}-, 094 \\
, 656 \\
25 \\
\end{array}$ & $\begin{array}{r}, 223 \\
, 283 \\
25 \\
\end{array}$ \\
\hline Pilipina & $\begin{array}{l}\text { Pearson Correlation } \\
\text { Sig. (2-tailed) } \\
\mathrm{N}\end{array}$ & $\begin{array}{r}, 452^{\star} \\
, 023 \\
25 \\
\end{array}$ & $\begin{array}{c}, 822^{* \star} \\
000 \\
25\end{array}$ & $\begin{array}{r}, 094 \\
, 656 \\
25 \\
\end{array}$ & $\begin{array}{r}1 \\
25 \\
\end{array}$ & $\begin{array}{r}, 135 \\
, 519 \\
25\end{array}$ \\
\hline Thailand & $\begin{array}{l}\text { Pearson Correlation } \\
\text { Sig. (2-tailed) } \\
\mathrm{N}\end{array}$ & $\begin{array}{r}, 199 \\
, 339 \\
25\end{array}$ & $\begin{array}{r}, 148 \\
, 480 \\
25\end{array}$ & $\begin{array}{r}, 223 \\
, 283 \\
25\end{array}$ & $\begin{array}{r}, 135 \\
, 519 \\
25\end{array}$ & $\begin{array}{r}1 \\
25\end{array}$ \\
\hline
\end{tabular}

Berdasarkan output analisis data Tabel 1.2. tentang nilai korelasi, pasar modal periode Juni Desember 2016 dari 5 negara yang memiliki korelasi positif yaitu Indonesia dengan Malaysia, Indonesia dengan Philipina, Indonesia dengan Thailand dengan korelasi yang signifikan, keculai Indonesia Thailand. Sedangkan nilai korelasi negatif yaitu: (Indonesia-Singapura), (MalaysiaSingapura), dan (Philipina-Singapura).

\section{Kesimpulan}

Berdasarkan analisis data yang telah dilakukan, kesimpulan yang diperoleh adalah periode Januari - Juni 2016 pasar modal dari 5 negara tidak ada yang memiliki korelasi negatif. Tetapi pada periode Juli - Desember 2016 Pasar modal dari 5 negara yang memiliki korelasi negatif yaitu: (Indonesia-Singapura), (Malaysia-Singapura), (Philipina-Singapura).

\section{DAFTAR PUSTAKA}

Bierens, Herman J. (2006). Cointegration Analysis. Pennsylvania State University.

Brigham, E. F., \& Daves, P. R. (2004). Mergers, LBO's, Divestures and Holding Companies. Intermediate Financial Management, 866-915.

Brooks, R. and Marco Del Negro. (2002). The Rise in Comovement Across National Stock Market: Market Integration or IT Bubble? Federal Roserve Bank of Atlanta Working Paper 2002-17a, September 2002.

Click, Reid W., and Michael G. Plummer. (2005), "Stock market integration in ASEAN after the Asian financial crisis." Journal of Asian Economics 16.1: 5-28.

Click. R.W.and Michael G. Plummer. (2003). Stock Market Integration in ASEAN after The Asian Financial Crisis. The International Cantre for the Study of East Asian Development, Kitakyushu, Japan.

Husnan, Suad. (2004). Dasar-dasar Teori Portofolio dan Analisis Sekuritas, Edisi Revisi, UPP AMP YKPN Yogyakarta.

Jogiyanto, H. M. (1998). Teori Portofolio dan Investasi. Yoygyakarta, Andi Offset.

Karolyi, G. A., \& Stulz, R. M. (1996). Why do markets move together? An investigation of US-Japan stock return comovements. The Journal of Finance, 51(3), 951-986.

Kian-Ping Lim, Hock-Ann Lee and L. Khim-Sen Liew. (2003). International Diversification Benefits in ASEAN Stock Markets: A Revisit, Labuan Schoolof International Business and Finance, University Malaysia, University Putra Malaysia. 
Lessard, D. R. (1973). International portfolio diversification: a multivariate analysis for a group of Latin American countries. The Journal of Finance, 28(3), 619-633.

Liaw, K. Thomas. (2005). Capital market. Thomson-Southwestern.

Markowitz., Harry. (1952). Selection, Portfolio, and Efficient Diversification, E. The journal of finance, 7(1), 77-91.

Nurhayati, Mafizatun. (2012) "Analisis Integrasi Pasar Modal Kawasan ASEAN dalam Rangka Menuju Masyarakat Ekonomi ASEAN." Seminar Nasional dan Call for Papers. Fakultas Ekonomi Unisbank.

Onay, C. (2007). Cointegration Analysis of Bovespo and Istambul Stock Exchanges. Oxford Business and Economics Conference. Oxford University. United Kingdom.

Plummer, Michael G., and Reid W. Click. (2005), "Bond market development and integration in ASEAN." International Journal of Finance \& Economics 10.2: 133-142.

Plummer, M. G., \& Click, R. W. (2006). The ASEAN economic community and the European experience.

Rodoni, Ahmad. (2011). Analisis Diversifikasi Investasi Internasional: Pada Beberapa Bursa Asia Pasifik dan Bursa Dunia. Lembaga Penelitian UIN. Jakarta.

Tandelilin, Eduardus. (2010). "Portofolio dan Investasi: Teori dan Aplikasi”. Edisi. Pertama. Yogyakarta : Kanisius.

Widyahartono Bob. Gordon B. Davis. (1992). Kerangka Dasar Sistem Informasi Manajemen. Jakarta: Pustaka Binaman Pressindo. 